\title{
The Shrink who Shrunk Himself: The Rise and Fall of Ronnie Laing
}

\author{
Authors: Robert M. Kaplan \\ Submitted: $\quad$ 12. July 2021 \\ Published: $\quad 26$. July 2021 \\ Volume: 8 \\ Issue: $\quad 3$ \\ Affiliation: University of Wollongong, Australia \\ Languages: English \\ Keywords: $\quad$ RD Laing, Antipsychiatry, Kingsley Hall, Psychoanalysis, \\ Categories: Medicine \\ Existentialism, David Cooper, Mary Barnes \\ DOI: $\quad$ 10.17160/josha.8.3.768
}

\section{Abstract:}

In the sixties, RD "Ronnie" Laing was the most famous psychiatrist in the world. He became the leading figure of the British anti-psychiatry movement and a public celebrity. Laing saw existentialism as the explanation for the problem of psychosis, leading to alienation. He was the charismatic spokesman for an era that wanted to hear that psychiatry was the punitive arm of the state and that psychosis was a creative response to the bourgeois family. With a group of like-minded psychiatrists, they set up the experimental Kingsley Hall. The most famous patient was Mary Barnes, who later achieved fame with her painting. The enterprise was chaotic and ended after five years in disarray. The key issue in producing schizophrenia for these psychiatrists was the bourgeois nuclear family, who became something of a hate figure to therapists. Laing steadily unwound, becoming incomprehensible and dissolute in public. He espoused transcendental meditation and rebirthing, but this had little impact. He died prematurely at the age of 62 . After decades, Laing is being seen in a new light. He has earned a number of biographies, is seen as a facilitator of the deinstitutionalisation movement and credited with chanaina the wav osvchiatric patients are reaarded - the

\section{JOSHA vouma assemene. Humanities and Arts}




\title{
Ronnie Laing: The Shrink who shrunk himself
}

\author{
Robert Kaplan
}

\section{Abstract}

In the sixties, RD "Ronnie" Laing was the most famous psychiatrist in the world. He became the leading figure of the British anti-psychiatry movement and a public celebrity.

Laing saw existentialism as the explanation for the problem of psychosis, leading to alienation. He was the charismatic spokesman for an era that wanted to hear that psychiatry was the punitive arm of the state and that psychosis was a creative response to the bourgeois family. With a group of like-minded psychiatrists, they set up the experimental Kingsley Hall. The most famous patient was Mary Barnes, who later achieved fame with her painting. The enterprise was chaotic and ended after five years in disarray.

The key issue in producing schizophrenia for these psychiatrists was the bourgeois nuclear family, who became something of a hate figure to therapists. Laing steadily unwound, becoming incomprehensible and dissolute in public. He espoused transcendental meditation and rebirthing, but this had little impact. He died prematurely at the age of 62 .

After decades, Laing is being seen in a new light. He has earned a number of biographies, is seen as a facilitator of the deinstitutionalization movement and credited with changing the way psychiatric patients are regarded - the patient is to be listened to. 


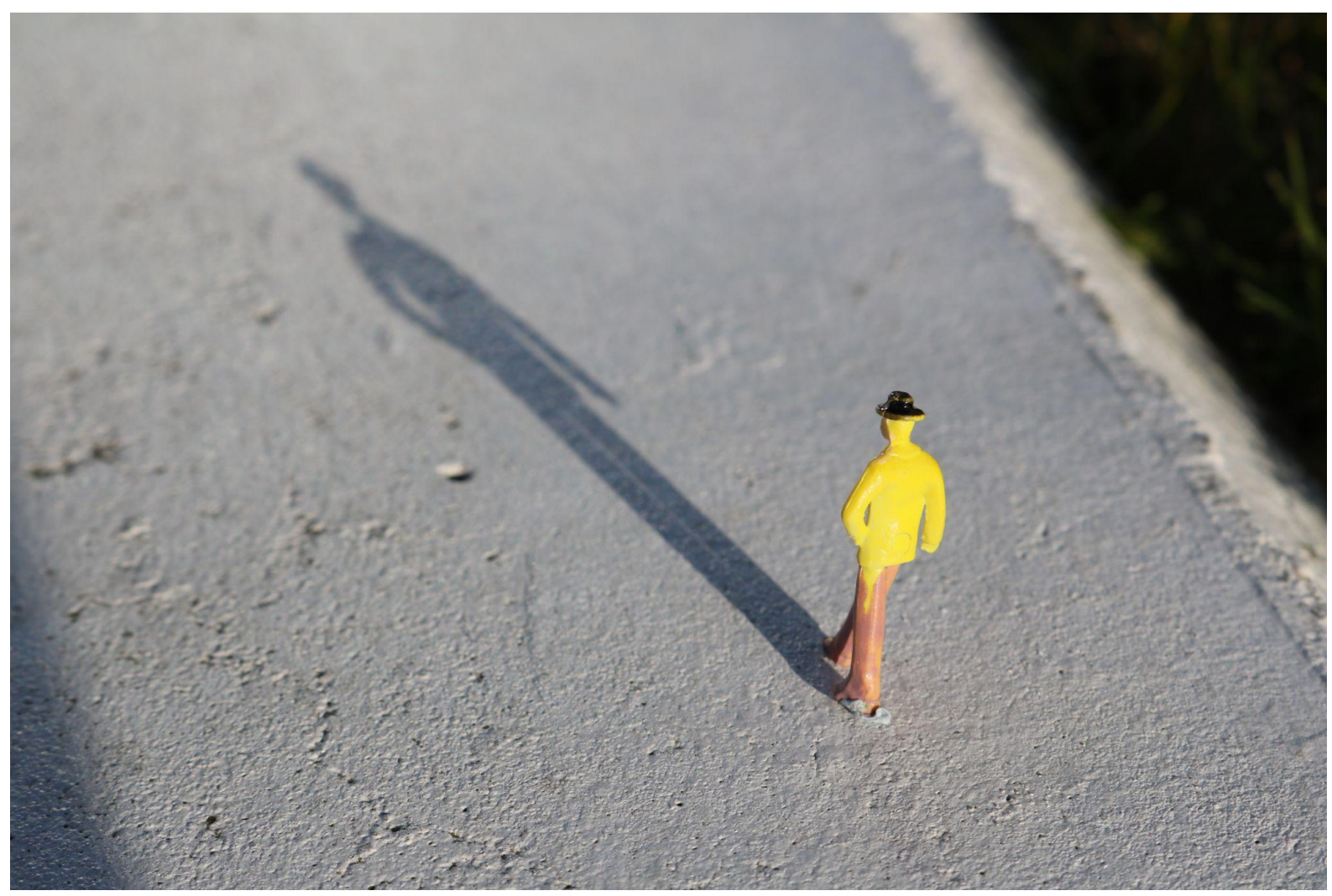

Who now remembers R D "Ronnie" Laing? In that garlanded era known as the Sixties (which went on well into the seventies), he was the most famous psychiatrist in the world; some said he was the successor to Sigmund Freud and Carl Jung.[1] He was the leading figure of the British anti-psychiatry movement. His books sold thousands of copies, were reprinted and translated into many languages. He gave lectures around the world, was a regular guest on radio and television shows, read his poetry to audiences and even made a record. He is the only psychiatrist to have his portrait hung in the Scottish National Portrait Gallery. 
But it all dwindled away, Laing morphed from proselytizing guru to international celebrity to public embarrassment. The end-product was an incoherent, profane, drunken sot going to almost any lengths to maintain his public image while turning his audience off in droves. When he died of a heart attack at 62 playing tennis in St Tropez in 1989[2], the obituaries commented on his decline, comparing it to the great promise of his early days and the hope he gave to so many patients. How did someone starting off with so much promise end up as a self-destructive caricature?

From an early age Laing, who had a remarkable inquiring bent, immersed himself in philosophy and saw existentialism as the explanation for the inscrutable and untreatable problem of psychosis. From this came alienation. Madness was caused by the oppressive bourgeois family and ultimately a creative experience. An only child, his mother was a stern, cold, difficult, if not bizarre, woman who had a powerful influence on his ideas about family life. The parental albatross hung heavily around Laing's neck and had a significant influence on his writing and behaviour. As dismaying, rejecting and confusing an environment it was, as an only child of high intelligence, all his material needs were granted.

His early experiences in psychiatry were shocking. Patients were dehumanised, treated like prisoners and subjected to appalling treatment like insulin coma therapy, electroconvulsive therapy and lobotomy. 
Having published his best-seller The Divided Self [3] - a book perfectly timed for the Counter-Culture - Laing trained as a psychoanalyst at the Tavistock Institute. He barely qualified, not least because of reservations about his personality raised by his analyst, Charles Rycroft; in the end, his undeniable intelligence persuaded the board to pass him.

Laing's writing made him the most prominent British anti-psychiatrist of the day and the leading figure in a like-minded group including Aaron Esterson, David Cooper, Joseph Berke, Sid Briskin, Clancy Sigal and Morton Schatzman. The politics of the movement, in accord with the times, was distinctly left-wing. In Gramsci-ite fashion, they were determined to change the psychiatric hegemony from callow psychiatrists who blasted patients with brutal treatment to a level playing field where the autonomy of the patient was recognised. It was the South African-born Cooper, a committed Marxist, who came up with the term anti-psychiatry, a label that Laing could never quite come to terms with. [4]

While paying due homage to Marxism, Laing was never a card-carrying member[5] (unlike Cooper who was positively anarchistic) and later dropped it completely.[6] He described the bourgeois nuclear family as a toxic cauldron that cooked the schizophrenic personality. The schizophrenic, he maintained, was torn between the identity imposed by their family and the identity that they experienced. People could not understand their communication when, in fact, they were creative but lonely in their isolation: they needed to be listened to. 
From this arose Laing's fundamental idea: Psychosis is a sane response to an insane world, the caput Nili to their hidden fears, thoughts and feelings. With these exposed, there would be regression to the foetal state and a new life could begin.

Good looking and articulate, with a dry wit, Laing was the charismatic spokesman for an era that wanted to hear that psychiatry was the punitive arm of the state and that psychosis was a creative response to the bourgeois family; that this all flowed into the hazy hallucinogenic world of the recreational drug user was a given. He became a star, welcomed by leftish intellectuals of the day: Jean Paul Sartre, Michael Foucault, Alan Ginsburg and Franco Basaglia.

Laing associated with a group who fitted perfectly into the Sixties Zeitgeist, their outdated work now seeming slightly incredible: Frieda Fromm-Reichman, Timothy Leary, Arthur Janov, Theodore Lidz, Gregory Bateson and John Rosen. He was given due respect in return as a leader in the field.

These psychiatrists, coming from widely differing backgrounds, had a central belief, amounting to dogma: schizophrenia was caused by the family; the pathogen, as it were, being the mother who was designated by such unlovely terms as the schizophrenogenic, toxic or refrigerator mother. Lidz based his wide-ranging conclusions on extensive research into 17 middle-class families.[7] Fromm-Reichman analysed schizophrenics at Chestnut Lodge.[8] Her claim of cures has not been sustained and there is doubt whether all of the patients there were actually schizophrenic. Janov's Primal Scream was just another of the gimcrack 
Sixties therapies that came and went.[9] Leary, of course, jettisoned any pretence at scientific rigour as soon as he could and headed straight for Hippie Guruland.

The doctrine that fuelled their work was Bateson's concept of the double bind - the spearhead of the sustained attack on schizophrenic parents that was an essential trope for those times.[10] The purported double-bind has been debunked and discarded. Few remember that Bateson came up with the idea when he needed a research topic for a grant.[11]

If Laing fitted in well with this company, he also found opposition. Thomas Szasz who refused to believe that psychiatric illness existed, said that Laing displayed 'an avoidance of responsibility for his first family, indefensible since his line had been that the breakdown of children could be attributed to parents and families.'[12] Their differences were more political than scientific; while Szasz was clearly of the right, Laing occupied the other end of the spectrum. An LSD proponent who did not support Laing's concepts was Humphry Osmond, who did the world's largest trial of LSD for alcoholics.[13] When the use of LSD was banned, he examined different medical models, finding Laing's model untenable.[14]

The enterprise reached its apogee at Kingsley Hall (1965-70) in the East End of London, a psychiatric commune where the boundaries between doctor and patient were removed, creating the utopian community that Cooper espoused. Over five years the anti-psychiatry movement and the patients "made a career of schizophrenia ". [15] The results were predictable and disastrous. LSD was dished 
out like sweets and disturbing behaviour of doctors and patients was inevitable.[16] It was an indication of the chaos that at least three of the therapists left their wives. Rock stars and other celebrities drifted in and out as if it was a zoo. Sean Connery, treated by Laing with LSD for stress[17], was disillusioned by what he saw, commenting that the way patients were treated was nothing less than "total barbaric behaviour on behalf of the psychiatrist".

The star turn at Kingsley Hall was Mary Barnes, a former nurse with schizophrenia.[18] She did not as much follow as dive into Laing's concept that only complete regression to the infantile state could purge the distorted circuits induced by the dysfunctional family. She lay naked in a cot, wearing a nappy and was bottle fed. She was preoccupied with defecating and urinating, covering herself in her faeces and sculpting and painting with it. David Berke spent virtually every hour with her until any boundaries between the two were lost. At one stage, he let her suck his nipple. When he lost his temper, he hit her in the face. Later he came to realise that the doctor-patient relationship required defined boundaries and that it was an illusion to believe that treatment could be done without those restrictions.

Barnes, eventually claiming recovery, became a painter (starting with her faeces) and wrote two books. The quality of her art remains a matter for critics, but it is highly likely that it was her celebrity status pulling in the crowds to the exhibitions.[19][20] Barnes, in fact, was not cured, having periods when she was 
hospitalised and remaining on medication.[21] This, of course, was always omitted from the hagiography.

The Kingsley Hall experiment ended in a maelstrom of animosity and recrimination with the leading figures going their own ways. By this point, over 100 people had lived there for varying periods. Esterson walked around with a book by Stalin under his arm. Sigal, having fallen out with Laing, paid him back by writing a novel modelled on the Kingsley Hall figures. Laing, who did not come out well out of this, succeeded in blocking its sale in the UK - so much for the freedom ethos he expounded. David Cooper, for his part, had several psychotic episodes and was later committed to a psychiatric ward in Argentina. After two patients jumped off the roof, the writing was on the wall.

Hubris followed by Nemesis. Running an analytic practice, guzzling LSD and having multiple affairs, Laing started to unwind. He became a public embarrassment, drunkenly babbling on television and at meetings. The celebrity, he complained, was all too much; he needed to get off the roundabout and come up with new ideas. The solution was to spend a year in the East seeking Nirvana with the Buddhists. But transcendence did not save the situation. The talks continued, the books still poured out, but the discourse became irrelevant, if not incomprehensible. Psychedelic usage continued but, true to his Glasgow roots, it was whisky in which he chose to drown himself. 
This was accompanied by a turbulent personal life. Laing was to have ten children to four different women. In an irony that showed the widening gap between his behaviour and his ideas, his children complained bitterly that he was a largely absent father and, when he did turn up, the results were devastating. His daughter Susan (1974) delivered her verdict: 'We've got too many problems for him. ... He can solve everybody else's problems but not our own.'[22] Adrian Laing, who wrote a biography of his father, summed it up. 'When people ask me what it was like to be RD Laing's son, I tell them it was a crock of shit.'[23] Laing would not be the first charismatic healer to have a callous or indifferent attitude towards his multifarious family, but his inexcusable behaviour makes him a gross hypocrite, if not a charlatan.

Whatever confusion or dismay he engendered, Laing was in the pantheon of medical charismatics; some prominent examples being Jacques Lacan, Masud Khan, Bernard Spilsbury and Christian Barnard. The charismatic doctor is seen as having special - magical - qualities by followers attracted by their accomplishments. But charisma follows its own rules. The dazzling cures must be continually delivered; once results start to falter, the followers leave. The charismatic then goes to extreme lengths to hold them followed by personal decline.

Consider what may be the most famous example of his special empathy. Visiting a ward with a group of doctors, they came to a naked mute woman rocking back and forth in a locked room. Laing, without ado, stripped off his clothes and sat next to her, rocking to the same rhythm. After a while, she spoke for the first 
time in months. Asked what he had done, the response was pure Laing: "Did it never occur to you to do that?"

To many, this is an awesome example of the charismatic healer at work. But consider the alternate view: it was an exaggerated party trick. Who now, and even then, could get away with this kind of behaviour with a patient, regardless of the outcome? It was the Droit du seigneur of the charismatic healer, not something that could be encouraged under any circumstances for other psychiatrists.

Following a well-worn path by Rank, Klein and other analytic figures, Laing jumped on the idea of birth trauma as the source of all psychological problems. Rebirthing was the answer, but it was hard to maintain the pretence. The birthing movement followed its own agenda and had no place for him. His ideas had gone down a blind end. He was burned out and he knew it. The shrink had shrunk himself.

What is to be made of RD Laing? If his ideas have gone out of fashion, there is no lack of interest in his life. He is the subject of articles, books, plays, documentaries and a novel.[24] The biography by his son Adrian is unsparing in its review of his life. The year he died, Laing proclaimed his legacy: "I feel I'm regarded (by my psychiatric colleagues) as a brilliant man who is pretty disturbed." 
After a hiatus of several decades, Laing's work is seen in a new light. When he started in psychiatry, the asylum population was at its height and the drug treatments now used were only slowly introduced. Asylum patients were regarded as mere shells with whom long conversations, let alone psychotherapy, was useless. Laing recognised the barriers between doctors, nurses and patients and pulled them down. From mere patients they became real people to be engaged with. There were many involved in this journey, but he deserves the most credit. His existential approach is a pointed reminder to return to the patient as a person to be listened to. The patient as a person must be included in the equation; just one example now is the regular inclusion of patient accounts in the journal Schizophrenia Bulletin.

There is now a disorderly retreat from the blind acceptance of neurotransmitters and other neuroscience memes. While no one denies the biological aspects of psychosis or the use of psychopharmaceuticals, a more nuanced approach is followed.

Another area where Laing gets credit is his role in the deinstitutionalization movement. The governmental decision to discharge long-term psychiatric patients into the community, deinstitutionalisation appeared a daunting endeavour. In eloquent style, Enoch Powell made his "water towers' ' speech in 1963 in which he called for the torch to be put to the "funeral pyre" of the great Victorian lunatic asylums. These stood "isolated, majestic, imperious, brooded over by the gigantic water-tower and chimney combined, rising unmistakable and daunting out of the 
countryside". A colossal undertaking, the powers of resistance should not for a moment be underestimated.[25]

Although it took two decades before the first British asylum was closed, Powell was wrong. [26] Governments, followed by psychiatrists and many - but not all - members of the public eagerly leaped on the bandwagon. In the USA, the Kennedy administration started it going, driven by the psychopharmacological drug revolution. The official view was that money would be saved, patients removed from the bleak asylum life, their problems treated with the new drugs.

Deinstitutionalisation was a social, penological and psychiatric disaster. Community facilities, with the best will in the world, could never provide adequate care. The broken-down, confused and psychotic patients drifted to the inner city as bag people, medicated themselves with alcohol and drugs, and filled the prisons. Patient advocacy groups - another benefit of Sixties anti-psychiatry - began to ask for the return of asylums, and it is doubtful if there is anyone working in psychiatry now who would not agree with this.

Kathleen Jones, praising Laing when delivering the Maudsley Lecture, stated that 'behind the rhetorical excesses and the studied irrationality there are some serious points for psychiatry to consider', in particular that 'the patient's view of what is happening to him is as valid as that of the therapist, and therapists ought to listen as well as to prescribe'.[27] 
Today we take this as a given, but we should not forget who led us to this: whether drunk, dishevelled, disruptive and declaiming, Laing was brilliant in his day, but inevitably followed the path of charismatic figures. The negative side of his work - blaming parents, especially mothers - for their child's schizophrenia, was misbegotten, if not unforgivable, but he was hardly alone in that.[28] When he applied his existential views to the practice of medicine in general, he was romantic, misconceived and anarchic.

Anthony Clare said it best: He gave a voice to madness. For that he should be remembered.[29] 
[1] Clare A. Ronald David Laing 1927-1989: an appreciation. Psychiatric Bulletin, 1990, 14, 87-88.

[2] His last words were "Doctor... What Fucking Doctor?

[3] Laing, R. D. (1960) The Divided Self. Tavistock, London.

[4] Cooper, D. (1967) Psychiatry and Anti-Psychiatry. Tavistock, London.

[5] Roberts R, Itten T. Laing and Szasz: Anti-psychiatry, Capitalism, and Therapy. Psychoanalytic Review; New York Vol. 93, Iss. 5, (Oct 2006): 781-99.

[6] Chapman, A (2016) Re-Coopering anti-psychiatry: David Cooper, revolutionary critic of psychiatry, Critical and Radical Social Work, vol 4, no 3, 421-32 .

[7] Edward Dolnick. Madness on the Couch: Blaming the Victim in the Heyday of Psychoanalysis. Simon and Schuster, New York, Pge 124.

[8] Edward Dolnick. Ibid, Pge 84.

[9] https://www.discovermagazine.com/health/whatever-happened-to-primal-therapy; accessed on 20 March 2020.

[10] Bateson, G., Jackson, D. D., Haley, J. \& Weakland, J. (1956) Toward

a theory of schizophrenia. Behavioral Science, 1, 251-264.

[11] Edward Dolnick. Ibid

[12] Roberts, Ron; Itten, Theodor. Laing and Szasz: Anti-psychiatry, Capitalism, and Therapy. Psychoanalytic Review; New York Vol. 93, Iss. 5, (Oct 2006): 781-99.

[13] Kaplan RM. Humphry Fortescue Osmond(1917-2004), a radical and conventional psychiatrist: The transcendent years. J Med Biogr. 2014 Mar 21.

[14] Siegler, M., Osmond, H. and Mann, H. (1969) Laing's model of madness, British Journal of Psychiatry, 115.

[15] Guattari, Felix. 1996. 'Mary Barnes' 'Trip.' In The Guattari Reader, edited by Gary Genosko, 46-54. Oxford: Blackwell, page 46. 
[16] Chapman, A. (2018) "May all Be Shattered into God": Mary Barnes and her journey through madness in Kingsley Hall. Journal of Medical Humanities, (doi: 10.1007/s10912-018-9517-1).

[17] https://www.bbc.com/news/uk-scotland-38816660; accessed on 20/03/2020.

[18] One issue remains unclear: did Mary Barnes have schizophrenia or was she a severely hysterical personality? Guattari had his doubts, referring to her as a a petit-bourgeois style of familialist regression - whatever that means it is not the accepted disorder known as schizophrenia.

[19] Tantam, D.. Something Sacred: Conversations, Writings, Paintings. By Mary Barnes with Ann Scott. London: Free Association Books. 1989. British Journal of Psychiatry, (1990) 157(6), 947-947.

[20] Guattari, Felix. 1996. 'Mary Barnes' 'Trip.' In The Guattari Reader, edited by Gary Genosko, 46-54. Oxford: Blackwell, page 54.

[21] Obituary. Mary Barnes. The Guardian; 13 July 2001: 23.

[22] Susan Laing, his second eldest daughter, as quoted in "RD Laing: The Abominable Family Man" in The Sunday Times (12 April 2009).

[23] Adrian Laing, as quoted in "RD Laing: The Abominable Family Man," The Sunday Times (12 April 2009).

[24] Adrian Laing. R.D. Laing A biography. The Laing Press, 2012.

[25] https://www.independent.co.uk/news/uk/the-politicians-take-over-the-asylum-1320131.html. Accessed on 3 April 2020.

[26] https://www.theguardian.com/society/2004/dec/08/mentalhealth.comment; Accessed 20/03/2020.

[27] Kathleen Jones, 'Society Looks at the Psychiatrist', British Journal of Psychiatry, 132 (1978), 321-32.

[28] Harrington A. Perspectives. The art of medicine. The fall of the schizophrenogenic mother. The Lancet.com Vol 379 April 7, 2012 , 1292-3.

[29] Clare A. Ronald David Laing 1927-1989: an appreciation. Psychiatric Bulletin ( 1990), 14, 87-88. 


\section{About the Author}

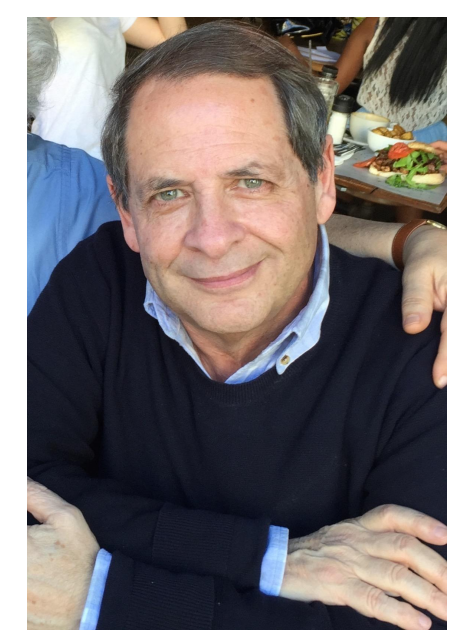

Clinical Associate Professor Robert M Kaplan is a forensic psychiatrist at the University of NSW, Western Sydney University and Wollongong University, Australia. He writes and lectures on forensic topics, history of medicine, crime, biography and genocide. His latest book "The King who Strangled his Psychiatrist and Other Dark Tales" is in Press. 